\title{
Reduction of Heavy Metals Level in the Waste Water Using Phytoremediation Technique
}

\author{
Azura Afrina*, Lazulva \\ UIN Sultan Syarif Kasim Riau, Panam, Pekanbaru - 28293, Indonesia
}

\section{*Email : azuraafrina@Gmail.com}

\begin{abstract}
This research was carried out due to the existence of the waste heavy metals in the aquatic environment, which was very harmful to the sustainability of the environment. The purpose of this research was to find out the reduction percentage of copper metal (Cu) on the waste. This research using method phytoremediation test. The plants used were water hyacinth (Eichornia crassipes) and algae (Hydrilla verticilata). This study was conducted three times of the repetition in each variable. The measurement of $\mathrm{Cu}$ concentration using Atomic Absorption Spectroscopy (AAS) flame. The Results of this research was found that the efficiency of the average reduction in the concentration of $\mathrm{Cu}$ by water hyacinth was $82.8368 \%$ and the efficiency of the average reduction in the concentration of $\mathrm{Cu}$ by algae was $63.4042 \%$.
\end{abstract}

Keywords: Heavy Metals, Waste Water, Phytoremediation

\section{Pendahuluan}

Limbah adalah buangan yang dihasilkan dari suatu proses produksi baik industri maupun domestik (rumah tangga), yang lebih dikenal sebagai sampah, yang kehadirannya pada suatu saat dan tempat tertentu tidak dikehendaki lingkungan karena tidak memiliki nilai ekonomis. Selain itu, dengan konsentrasi dan kuantitas tertentu, kehadiran limbah dapat berdampak negatif terhadap lingkungan terutama bagi kesehatan manusia, sehingga perlu dilakukan penanganan terhadap limbah. Tingkat bahaya keracunan yang ditimbulkan oleh limbah tergantung pada jenis dan karakteristik limbah. ${ }^{1}$ Salah satu jenis limbah yang sangat berbahaya adalah limbah yang mengandung logam berat. Dimana logam berat adalah logam yang tidak bisa didegradasi oleh mikroorganisme, sehingga apabila tidak segera dilakukan pengolahan terhadap limbah tersebut, maka limbah tersebut akan terus-menerus menumpuk di lingkungannya dan akan menimbulkan pencemaran.
Salah satu produsen yang menghasilkan limbah yang mengandung logam berat adalah pabrik. Berdasarkan data dari suatu penelitian, disebutkan bahwa nilai rata-rata konsentrasi logam berat tembaga $(\mathrm{Cu})$ pada limbah cair di salah satu pabrik karet yang terdapat di Kota Pekanbaru adalah sebesar 1,436 x 10-6 kg/L atau 1,436 ppm. Sementara itu, konsentrasi standar maksimum yang ditetapkan oleh Dep. Kes. R.I. untuk $\mathrm{Cu}$ adalah sebesar $0,05 \mathrm{mg} / \mathrm{L}$ atau 0,05 ppm untuk batas maksimal yang dianjurkan, dan sebesar $1,5 \mathrm{mg} / \mathrm{L}$ atau 1,5 ppm sebagai batas maksimal yang diperbolehkan. $^{2}$ Hal ini tentu memperlihatkan bahwa kadar logam berat $\mathrm{Cu}$ pada pabrik tersebut sudah hampir membahayakan, karena hampir melewati ambang batas yang diperbolehkan.

Salah satu cara yang paling sederhana, mudah dan murah untuk mengurangi kadar logam berat pada limbah tersebut adalah dengan menggunakan teknik fitoremediasi. Fitoremediasi merupakan penggunaan tanaman untuk menghilangkan, 
memindahkan, menstabilkan atau menghancurkan bahan pencemar baik itu senyawa organik maupun anorganik. $^{3}$

Semua tumbuhan mampu menyerap logam dalam jumlah yang bervariasi, tetapi beberapa tumbuhan mampu mengakumulasi unsur logam tertentu dalam konsentrasi yang cukup tinggi. ${ }^{4}$ Hanya saja, dalam penelitian ini dipilih tumbuhan eceng gondok (Eichornia crassipes) dan ganggang (Hydrilla verticilata). Eceng gondok dipilih karena berdasarkan penelitian sebelumnya yang dilakukan oleh Suwondo, dkk., dinyatakan bahwa tanaman eceng gondok menunjukkan kemampuan mengakumulasi logam $\mathrm{Cu}{ }^{5}$ Sedangkan ganggang dipilih karena berdasarkan penelitian Sumiyati, dkk yang menyatakan bahwa tanaman Hydrilla mampu menurunkan kadar logam $\mathrm{Cu}$ yang terkandung dalam air limbah kerajinan perak. ${ }^{6}$

\section{Metodologi Penelitian}

\subsection{Bahan kimia, peralatan dan instrumentasi}

Bahan-bahan yang digunakan yaitu limbah cair industri pabrik karet; tumbuhan air, yakni: eceng gondok (Eichornia crassipes) dan ganggang (Hydrilla verticilata); air suling; Asam Nitrat $\left(\mathrm{HNO}_{3}\right)$ dan Tembaga Nitrat $\left(\mathrm{Cu}\left(\mathrm{NO}_{3}\right)_{2}\right)$.

Alat-alat yang digunakan dalam penelitian yaitu: $\mathrm{pH}$ meter, lemari asam, lemari pendingin, 6 buah toples plastik 5 liter, 3 buah jerigen 10 liter, 6 buah gelas piala $250 \mathrm{~mL}, 1$ buah gelas piala 1000 $\mathrm{mL}, 1$ buah gelas ukur $100 \mathrm{~mL}, 1$ buah gelas ukur $10 \mathrm{~mL}$, masing-masing 1 buah labu ukur $100 \mathrm{~mL}$; $500 \mathrm{~mL}$; dan $1000 \mathrm{~mL}$, masing-masing 1 buah pipet volumetrik $5 \mathrm{~mL} ; 10 \mathrm{~mL}$; dan $20 \mathrm{~mL}, 3$ buah pipet tetes, 1 buah corong gelas, 7 buah botol plastik, 1 buah kaca arloji, hot plate, kertas saring, alluminium foil, tisu, timbangan analitik, timbangan manual dan labu semprot. Sementara itu, instrumen utama yang digunakan adalah Atomic Absorption Spectroscopy (AAS)-nyala (Type: AA, Model Name: AA-7000).

\subsection{Prosedur penelitian \\ Teknik Pengambilan Sampel}

Teknik pengambilan sampel yang digunakan dalam penelitian ini adalah pengambilan sampel random (cuplikan random, cuplikan acak). Dimana cara pengambilan sampel ini dilakukan terhadap bahan yang serba sama (homogen) atau dianggap serba sama. Larutan/ suspensi harus digojog sampai homogen, baru dilakukan pengambilan sampel secara random. ${ }^{7}$

\section{Preparasi Sampel}

Sampel tumbuhan air, yakni: eceng gondok (Eichornia crassipes) dan ganggang (Hydrilla verticilata) dicuci bersih dengan air dan selanjutnya dilakukan aklimasi selama 1 minggu. Sedangkan limbah cair yang telah diambil, disimpan dalam jerigen tertutup dan langsung digunakan untuk proses penelitian.

\section{Uji Pendahuluan}

Pada uji pendahuluan, dilakukan analisa terhadap konsentrasi logam berat tembaga $(\mathrm{Cu})$ pada limbah cair hasil pengolahan karet dengan menggunakan instrumen Atomic Absorption Spectroscopy (AAS)-nyala. Uji pendahuluan ini dilakukan guna mengetahui konsentrasi awal logam berat $\mathrm{Cu}$ dalam limbah cair hasil pengolahan karet tersebut.

\section{Uji Fitoremediasi}

Masukkan sampel limbah cair sebanyak $4 \mathrm{~L}$ ke dalam wadah (toples plastik). Kemudian masukkan masing-masing 1 rumpun tumbuhan eceng gondok (Eichornia crassipes) dengan berat 50 gram dan ganggang (Hydrilla verticillata) dengan berat 50 gram kedalam wadah (toples $5 \mathrm{~L}$ ) yang berbeda. Dalam hal ini dilakukan 3 kali pengulangan pada masing-masing variabel. Sehingga totalnya ada enam wadah yang berisi dua jenis tumbuhan air yang akan diamati dalam penelitian ini. Masing-masing wadah diberi nama P1A, P1B, P1C, P2A, P2B, P2C. Dimana P1A; $\mathrm{P} 1 \mathrm{~B}$; dan $\mathrm{P} 1 \mathrm{C}$ berisikan tumbuhan eceng gondok, sedangkan P2A; P2B; dan P2C berisikan tumbuhan ganggang.

Setelah itu dilakukan pengamatan selama 9 hari. Pada hari ke 1, 3, 5, 7, dan 9 dilakukan pengukuran $\mathrm{pH}$ dan suhu limbah cair. Sementara itu, pada hari ke-9 dilakukan kembali pengukuran kadar (konsentrasi) akhir logam $\mathrm{Cu}$ pada masingmasing sampel limbah cair dengan menggunakan instrumen Atomic Absorption Spectroscopy (AAS)nyala. ${ }^{8}$ Selanjutnya, hasil pengukuran $\mathrm{pH}$ dan suhu sampel limbah cair dan hasil pengujian konsentrasi logam $\mathrm{Cu}$ juga dibuat kedalam bentuk grafik untuk memperlihatkan perubahan konsentrasi awal dan akhir dari masing-masing sampel limbah cair.

Preparasi Sampel Limbah Cair untuk
Pengukuran Kadar Logam Tembaga (Cu)
Menggunakan Instrumen Atomic Absorption
Spectroscopy (AAS)-Nyala


Masukkan $100 \mathrm{~mL}$ sampel yang sudah dikocok sampai homogen kedalam gelas piala 250 $\mathrm{mL}$. Tambahkan $5 \mathrm{~mL}$ asam nitrat dan panaskan di pemanas listrik sampai larutan contoh uji hampir kering. Ditambahkan $50 \mathrm{~mL}$ air suling, masukan ke dalam labu ukur $100 \mathrm{~mL}$ melalui kertas saring dan ditepatkan $100 \mathrm{~mL}$ dengan air suling. ${ }^{9}$

\section{Pembuatan Larutan Standar Logam Tembaga} (Cu)

Untuk pembuatan larutan induk logam tembaga $(\mathrm{Cu}) 1.000$ ppm, timbang $\mathrm{Cu}\left(\mathrm{NO}_{3}\right)_{2}$ sebanyak 3 gram dan selanjutnya larutkan dengan air suling di dalam labu ukur $1.000 \mathrm{~mL}$, lalu diencerkan hingga tanda batas. Selanjutnya, untuk pembuatan larutan baku logam $\mathrm{Cu} 100$ ppm, pipet $10 \mathrm{~mL}$ larutan induk $\mathrm{Cu} 1.000 \mathrm{ppm}$ ke dalam labu ukur $100 \mathrm{~mL}$, dan tepatkan dengan larutan pengencer (air suling) sampai tanda tera. Sedangkan untuk pembuatan larutan baku logam $\mathrm{Cu} 10$ ppm, pipet $50 \mathrm{~mL}$ larutan standar $\mathrm{Cu} 100$ ppm ke dalam labu ukur $500 \mathrm{~mL}$, dan tepatkan dengan larutan pengencer (air suling) sampai tanda tera.

Untuk pembuatan larutan kerja logam $\mathrm{Cu}$, pipet $0 \mathrm{~mL} ; 2 \mathrm{~mL} ; 5 \mathrm{~mL} ; 10 \mathrm{~mL} ; 20 \mathrm{~mL} ; 30 \mathrm{~mL}$ dan $40 \mathrm{~mL}$ larutan baku $\mathrm{Cu} 10$ ppm masing-masing ke dalam labu ukur $100 \mathrm{~mL}$. Tambahkan larutan pengencer (air suling yang ditambahkan dengan $\mathrm{HNO}_{3}$ hingga $\mathrm{pH}$ menjadi 2) sampai tepat tanda tera sehingga diperoleh konsentrasi logam $\mathrm{Cu}$ sebesar $0,0 \mathrm{ppm} ; 0,2 \mathrm{ppm} ; 0,5 \mathrm{ppm} ; 1,0 \mathrm{ppm} ; 2,0$ ppm; 3,0 ppm dan 4,0 ppm. ${ }^{9}$

\section{Pengukuran Kadar Logam Tembaga (Cu) Limbah Cair \\ Dilakukan pengukuran terhadap kadar logam} tembaga $(\mathrm{Cu})$ pada limbah cair dengan menggunakan instrumen Atomic Absorption Spectroscopy (AAS)-nyala. Kemudian data hasil pengukuran konsentrasi logam $\mathrm{Cu}$ pada limbah cair yang telah diolah dengan teknik fitoremediasi dibandingkan dengan data hasil pengukuran konsentrasi logam $\mathrm{Cu}$ pada limbah cair hasil pengolahan pabrik. Selanjutnya dilakukan penghitungan efisiensi penurunan (\%) kadar logam berat $\mathrm{Cu}$ pada limbah dengan menggunakan rumus efisiensi penurunan (\%).

$$
\text { Penurunan }(\mathrm{Ep})=\left(\frac{A_{0}-A_{t}}{A_{0}}\right) \times 100 \% .{ }^{10}
$$

\section{Hasil dan Diskusi}

\subsection{Analisis hasil karakterisasi}

Sampel limbah cair yang digunakan dalam penelitian ini adalah limbah cair hasil pengolahan karet di salah satu pabrik karet yang ada di Kota Pekanbaru. Limbah cair ini dipilih berdasarkan data dari suatu penelitian yang menyebutkan bahwa nilai rata-rata konsentrasi logam berat tembaga $(\mathrm{Cu})$ limbah cair pada pabrik tersebut adalah sebesar $1,436 \times 10^{-6} \mathrm{~kg} / \mathrm{L}$ atau $1,436 \mathrm{ppm}$. Hal ini tentu memperlihatkan bahwa kadar logam berat tembaga $(\mathrm{Cu})$ pada pabrik tersebut sudah hampir membahayakan, karena hampir melewati ambang batas yang diperbolehkan. Dimana konsentrasi standar maksimum yang ditetapkan oleh Dep. Kes. R.I. untuk $\mathrm{Cu}$ ini adalah sebesar $0,05 \mathrm{mg} / \mathrm{L}$ atau 0,05 ppm untuk batas maksimal yang dianjurkan, dan sebesar $1,5 \mathrm{mg} / \mathrm{L}$ atau $1,5 \mathrm{ppm}$ sebagai batas maksimal yang diperbolehkan. ${ }^{2}$

\section{Preparasi Sampel}

Sampel tumbuhan air yang digunakan dalam penelitian ini adalah eceng gondok (Eichornia crassipes) dan ganggang (Hydrilla verticilata). Alasan utama dalam pemilihan eceng gondok karena kemampuannya dalam mengakumulasi logam $\mathrm{Cu}^{5}$ Sedangkan alasan utama pemilihan ganggang karena tanaman hydrilla mampu menurunkan logam $\mathrm{Cu}$ yang terkandung dalam air limbah kerajinan perak. ${ }^{6}$

Selain itu, pemilihan eceng gondok dikarenakan eceng gondok merupakan tanaman dengan toleransi tinggi, dapat tumbuh baik dalam limbah, pertumbuhannya cepat, dapat menyerap dan mengakumulasi logam dengan baik dan dalam waktu yang singkat. ${ }^{3}$ Sementara alasan lain dalam memilih tumbuhan ganggang karena tumbuhan ganggang dapat mentolerir toksisitas logam berat, sehingga dapat tumbuh walaupun media tumbuhnya terkontaminasi oleh logam berat. ${ }^{11}$

Sampel tumbuhan air yang telah dipilih kemudian dicuci bersih dengan air dan selanjutnya dilakukan aklimasi selama 1 minggu. Aklimasi bertujuan agar tumbuhan dapat beradaptasi dengan lingkungan hidup yang baru setelah di pindahkan dari lingkungan hidup yang sebelumnya. Sementara itu, sampel limbah cair yang telah diambil dan disimpan dalam jerigen dapat langsung digunakan untuk proses penelitian.

\section{Uji Pendahuluan}

Uji pendahuluan ini dilakukan guna mengetahui konsentrasi awal logam berat tembaga (Cu) dalam limbah cair hasil pengolahan karet tersebut. Dari hasil uji kadar logam $\mathrm{Cu}$ dengan 
menggunakan instrumen Atomic Absorption Spectroscopy (AAS)-nyala, didapati kadar awal dari logam $\mathrm{Cu}$ yang terdapat pada limbah cair pabrik karet tersebut pada saat itu adalah 0,1175 ppm. Kadar ini memang tidak melampaui ambang batas maksimal logam $\mathrm{Cu}$ yang ditetapkan oleh Dep. Kes. R.I., yakni sebesar $1,5 \mathrm{mg} / \mathrm{L}$ atau 1,5 ppm. ${ }^{2}$ Namun menurut Heryando Palar (2004) biota perairan sangat peka terhadap kelebihan $\mathrm{Cu}$ dalam perairan tempat hidupnya. Konsentrasi $\mathrm{Cu}$ terlarut yang mencapai 0,01 ppm akan mengakibatkan kematian bagi fitoplankton. ${ }^{4}$ Dimana fitoplankton merupakan produsen primer terpenting di dalam suatu ekosistem perairan.

\section{Uji Fitoremediasi}

Dalam penelitian ini dilakukan 3 kali pengulangan terhadap masing-masing variabel. Sehingga totalnya ada enam wadah yang berisi dua jenis tumbuhan air yang akan diamati dalam penelitian ini. Pengamatan dilakukan selama 9 hari. Pada hari ke 1, 3, 5, 7, dan 9 dilakukan pengukuran $\mathrm{pH}$ dan suhu limbah cair. Pengukuran $\mathrm{pH}$ dan suhu dilakukan karena derajat keasaman $(\mathrm{pH})$ sangat erat hubungannya dengan kandungan logam berat yang terdapat di dalam sungai, semakin banyak bahan pencemar (kandungan logam berat) yang berada di dalam sungai maka akan mengakibatkan rendahnya nilai $\mathrm{pH}$ yang membuat kesadahan air yang bersifat asam. Sementara bahan-bahan kimia yang dikeluarkan oleh limbah industri seperti logam berat yang berada di sungai, mengakibatkan peningkatan suhu di suatu perairan tersebut. ${ }^{12}$ Oleh karena itu, dapat juga disimpulkan bahwa, semakin rendah nilai $\mathrm{pH}$ pada suatu perairan, dapat menandakan bahwa bahan pencemar (kandungan logam berat) semakin banyak dan begitu pula sebaliknya. Sementara itu, semakin tinggi suhu atau temperatur pada suatu perairan, maka dapat menandakan bahwa bahan pencemar (kandungan logam berat) juga semakin banyak dan begitu pula sebaliknya. Berdasarkan pengukuran $\mathrm{pH}$ limbah cair yang ditambahkan tanaman eceng gondok, diperoleh data sebagai berikut:

Tabel 1. Data hasil pengukuran $\mathrm{pH}$ yang ditambahkan tumbuhan eceng gondok.

\begin{tabular}{ccccc}
\hline \multirow{2}{*}{ No } & \begin{tabular}{c} 
Waktu \\
Pengujian \\
\cline { 3 - 5 } (Hari ke-)
\end{tabular} & P1A & P1B & P1C \\
\hline 1 & 1 & 6,54 & 6,54 & 6,54 \\
2 & 3 & 6,91 & 6,88 & 6,94 \\
3 & 5 & 6,91 & 6,89 & 6,96
\end{tabular}

$\begin{array}{llccc}4 & 7 & 7,19 & 7,21 & 7,23 \\ 5 & 9 & 7,2 & 7,23 & 7,24\end{array}$

Dari data Tabel 1 dapat dilihat bahwa $\mathrm{pH}$ sampel limbah cair dari hari ke hari terus mengalami kenaikan. Kenaikan $\mathrm{pH}$ ini terjadi karena adanya proses fotosintesis, denitrifikasi, pemecahan nitrogen organik dan reduksi sulfat. ${ }^{13}$ Hal ini menunjukkan bahwasanya, selain berhubungan dengan penurunan kelarutan logam, kenaikan $\mathrm{pH}$ juga dipengaruhi oleh beberapa proses lainnya. Sementara itu, berdasarkan pengukuran terhadap $\mathrm{pH}$ limbah cair yang ditambahkan tanaman ganggang, diperoleh data sebagai berikut:

Tabel 2. Data hasil pengukuran $\mathrm{pH}$ limbah cair yang ditambahkan tumbuhan ganggang.

\begin{tabular}{ccccc}
\hline & Waktu & \multicolumn{3}{c}{ Wadah } \\
\cline { 3 - 5 } No. & $\begin{array}{c}\text { Pengujian } \\
\text { (Hari ke-) }\end{array}$ & P2A & P2B & P2C \\
\hline 1 & 1 & 6,54 & 6,54 & 6,54 \\
2 & 3 & 8,35 & 8,38 & 8,34 \\
3 & 5 & 8,94 & 8,93 & 8,87 \\
4 & 7 & 9 & 8,94 & 8,96 \\
5 & 9 & 9,02 & 8,95 & 9,07 \\
\hline
\end{tabular}

Dari data Tabel 2 dapat dilihat bahwa $\mathrm{pH}$ sampel limbah cair yang ditambahkan tumbuhan ganggang tersebut dari hari ke hari juga terus mengalami kenaikan. Selain itu dilakukan juga pengukuran terhadap suhu atau temperatur limbah cair Berdasarkan pengukuran terhadap suhu limbah cair yang ditambahkan tanaman eceng gondok, diperoleh data sebagai berikut:

Tabel 3. Data hasil pengukuran suhu limbah cair yang ditambahkan tumbuhan eceng gondok.

\begin{tabular}{ccccc}
\hline & Waktu & \multicolumn{3}{c}{ Wadah } \\
\cline { 3 - 5 } No. & $\begin{array}{c}\text { Pengujian } \\
\text { (Hari ke-) }\end{array}$ & P1A & P1B & P1C \\
\hline 1 & 1 & $30,1{ }^{0} \mathrm{C}$ & $30,1{ }^{0} \mathrm{C}$ & $30,1{ }^{0} \mathrm{C}$ \\
2 & 3 & $29,8{ }^{\circ} \mathrm{C}$ & $29,8{ }^{\circ} \mathrm{C}$ & $29,8{ }^{\circ} \mathrm{C}$ \\
3 & 5 & $29,7{ }^{\circ} \mathrm{C}$ & $29,8{ }^{\circ} \mathrm{C}$ & $29,8{ }^{\circ} \mathrm{C}$ \\
4 & 7 & $29,5^{\circ} \mathrm{C}$ & $29,8{ }^{0} \mathrm{C}$ & $29,8{ }^{\circ} \mathrm{C}$ \\
5 & 9 & $29,3^{\circ} \mathrm{C}$ & $29,8{ }^{\circ} \mathrm{C}$ & $29,8^{\circ} \mathrm{C}$ \\
\hline
\end{tabular}

Dari data Tabel 3 dapat dilihat bahwa suhu sampel limbah cair dari hari ke hari terus mengalami penurunan. Hal ini dikarenakan nilai pH dipengaruhi oleh suhu dan salinitas air. Dalam hal ini suhu yang mengalami penurunan menyebabkan kenaikan kelarutan oksigen air 
sehingga nilai $\mathrm{pH}$ menjadi naik (basa). ${ }^{13}$ Sementara itu, berdasarkan pengukuran terhadap suhu limbah cair yang ditambahkan tanaman ganggang, diperoleh data sebagai berikut:

Tabel 4. Data hasil pengukuran suhu limbah cair yang ditambahkan tumbuhan ganggang.

\begin{tabular}{ccccc}
\hline & $\begin{array}{c}\text { Waktu } \\
\text { No. }\end{array}$ & \multicolumn{3}{c}{ Wengujian } \\
\cline { 3 - 5 } (Hari ke-) & P2A & P2B & P2C \\
\hline 1 & 1 & $30,1{ }^{\circ} \mathrm{C}$ & $30,1{ }^{\circ} \mathrm{C}$ & $30,1{ }^{\circ} \mathrm{C}$ \\
2 & 3 & $29,8{ }^{\circ} \mathrm{C}$ & $29,8^{\circ} \mathrm{C}$ & $29,9^{\circ} \mathrm{C}$ \\
3 & 5 & $29,7{ }^{\circ} \mathrm{C}$ & $29,7{ }^{\circ} \mathrm{C}$ & $29,8{ }^{\circ} \mathrm{C}$ \\
4 & 7 & $29,1{ }^{\circ} \mathrm{C}$ & $29,3{ }^{\circ} \mathrm{C}$ & $29,5^{\circ} \mathrm{C}$ \\
5 & 9 & $29,1{ }^{\circ} \mathrm{C}$ & $29,2{ }^{\circ} \mathrm{C}$ & $29,1{ }^{\circ} \mathrm{C}$ \\
\hline
\end{tabular}

Dari data Tabel 4 dapat dilihat bahwa suhu sampel limbah cair yang ditambahkan tumbuhan ganggang dari hari ke hari juga terus mengalami penurunan, sama halnya dengan sampel limbah cair yang ditambahkan tumbuahan eceng gondok. Sementara itu, pada hari ke-9 dilakukan kembali pengukuran kadar (konsentrasi) akhir logam $\mathrm{Cu}$ pada masing-masing sampel limbah cair dengan menggunakan instrumen Atomic Absorption Spectroscopy (AAS)-nyala. ${ }^{8}$

\section{Destruksi Sampel Limbah Cair}

Proses destruksi yang dilakukan dalam penelitian ini adalah proses destruksi basah. Destruksi basah bertujuan untuk menentukan unsur-unsur dengan konsentrasi yang rendah. Destruksi basah dilakukan dengan cara menguraikan bahan organik dalam larutan asam pengoksidasi pekat dengan pemanasan sampai jernih. Mineral anorganik akan tertinggal dan larut dalam larutan asam kuat. Larutan asam nitrat pekat merupakan asam yang paling efektif dan paling sering digunakan dalam destruksi basah karena dapat memecah sampel menjadi senyawa yang mudah terurai dan larutan asam nitrat pekat sendiri sukar menguap. Preparasi sampel dengan metode destruksi basah dilakukan pada suhu rendah dan dengan penambahan campuran asam kuat untuk mendestruksi senyawa organik dan bahan lain dalam sampel. ${ }^{14}$

\section{Penentuan Kadar Logam Berat Tembaga}

Penentuan kadar logam berat tembaga $(\mathrm{Cu})$ dalam penelitian ini dilakukan dengan menggunakan instrumen Atomic Absorption Spectroscopy (AAS)-nyala dengan merk Shimadzu tipe AA-7000. Mengukur logam berat $\mathrm{Cu}$ pada panjang gelombang $324,8 \mathrm{~nm}$, dengan tipe nyala Udara- $\mathrm{C}_{2} \mathrm{H}_{2}$, kecepatan aliran gas pembakar 1,8
L/min, Kecepatan aliran udara 15,0 dan ketinggian tungku 7,0 mm.

Pengujian kadar logam berat $\mathrm{Cu}$ dilakukan dengan mengacu pada prosedur Standar Nasional Indonesia (SNI) 06-6989.6-2004, tentang cara uji logam $\mathrm{Cu}$ dengan Spektrofotometri Serapan Atom (SSA)-nyala. Hasil uji kadar logam berat $\mathrm{Cu}$ pada limbah cair hasil pengolahan pabrik karet dengan menggunakan instrumen AAS disajikan pada Tabel 6 berikut ini:

Tabel 6. Tabel data hasil pengujian konsentrasi $\operatorname{logam} \mathrm{Cu}$ pada sampel limbah cair

\begin{tabular}{|c|c|c|c|c|}
\hline \multirow[t]{2}{*}{ No } & \multirow[t]{2}{*}{ Wadah } & \multirow[t]{2}{*}{$\begin{array}{c}\text { Tumbuhan } \\
\text { Air }\end{array}$} & \multicolumn{2}{|c|}{$\begin{array}{c}\text { Perubahan } \\
\text { Konsentrasi Logam } \\
\mathrm{Cu}(\mathrm{ppm})\end{array}$} \\
\hline & & & Awal & Akhir \\
\hline 1 & P1A & Eceng & $11,75 \times 10^{-2}$ & $2,46 \times 10^{-2}$ \\
\hline 2 & P1B & gondok & $11,75 \times 10^{-2}$ & $2,15 \times 10^{-2}$ \\
\hline 3 & $\mathrm{P} 1 \mathrm{C}$ & $\begin{array}{l}\text { (Eichornia } \\
\text { crassipes) }\end{array}$ & $11,75 \times 10^{-2}$ & $1,44 \times 10^{-2}$ \\
\hline 4 & P2A & & $11,75 \times 10^{-2}$ & $2,28 \times 10^{-2}$ \\
\hline 5 & $\mathrm{P} 2 \mathrm{~B}$ & Ganggang & $11,75 \times 10^{-2}$ & $6,96 \times 10^{-2}$ \\
\hline 6 & $\mathrm{P} 2 \mathrm{C}$ & $\begin{array}{c}\text { (Hydrilla } \\
\text { verticilata) }\end{array}$ & $11,75 \times 10^{-2}$ & $3,66 \times 10^{-2}$ \\
\hline
\end{tabular}

Dari data Tabel 6, terlihat bahwa seluruh variabel mengalami penurunan konsentrasi logam berat $\mathrm{Cu}$. Hanya saja, selisih penurunan konsentrasi pada beberapa variabel terlihat berbeda jauh dari yang lainnya. Perbedaan konsentrasi ini terjadi karena beberapa faktor. Diantaranya karena kondisi fisiologi tumbuhan yang tidak sama. Misalnya ketebalan akar, panjangnya akar, serta lebarnya daun.

Selain itu, hal ini juga bisa disebabkan oleh pengaruh keberadaan mikroorganisme pada akar ataupun pada limbah cair. Sementara itu, berdasarkan perhitungan menggunakan rumus efisiensi penurunan (\%) kadar logam berat $\mathrm{Cu}$ pada limbah cair diperoleh data sebagai berikut:

Tabel 7. Tabel data efisiensi penurunan (\%) kadar tembaga pada sampel limbah cair

\begin{tabular}{cccc}
\hline No & Wadah & $\begin{array}{c}\text { Tumbuhan } \\
\text { Air }\end{array}$ & $\begin{array}{c}\text { Efisiensi Penurunan } \\
\text { (\%) Kadar Logam } \\
\text { Tembaga (Cu) pada } \\
\text { Sampel Limbah Cair }\end{array}$ \\
\hline 1 & P1A & Eceng & $79,0638 \%$ \\
2 & P1B & gondok & $81,7021 \%$ \\
3 & P1C & (Eichornia & $87,7446 \%$ \\
\hline 4 & P2A & Hydrilla & \\
\hline
\end{tabular}




\begin{tabular}{cccc}
\hline No & Wadah & $\begin{array}{c}\text { Tumbuhan } \\
\text { Air }\end{array}$ & $\begin{array}{c}\text { Efisiensi Penurunan } \\
\text { (\%) Kadar Logam } \\
\text { Tembaga (Cu) pada } \\
\text { Sampel Limbah Cair }\end{array}$ \\
\hline 5 & P2B & (Hydrilla & $40,7659 \%$ \\
6 & P2C & verticilata) & $68,8510 \%$ \\
\hline
\end{tabular}

Berdasarkan data pada Tabel 7 dapat diketahui bahwa efisiensi penurunan kadar logam berat $\mathrm{Cu}$ oleh eceng gondok lebih besar dari pada efisiensi penurunan kadar logam berat $\mathrm{Cu}$ oleh ganggang. Sementara itu, jika dirata-ratakan masing-masing efisiensi penurunan kadar logam berat $\mathrm{Cu}$ oleh eceng gondok dan ganggang, maka akan di dapatkan nilai $82,8368 \%$ untuk hasil penyerapan oleh eceng gondok dan 63,4042\% untuk hasil penyerapan oleh ganggang.

Kemampuan menyerap kontaminan yang dimiliki oleh tumbuhan dipengaruhi oleh beberapa faktor, diantaranya luas permukaan tubuh tumbuhan dan ukuran tumbuhan. Dimana, menurut hasil penelitian dijelaskan bahwa ganggang (Hydrilla verticillata) mempunyai luas permukaan tubuh yang kecil sehingga kontak dengan logam semakin kecil. Selain itu, ukuran ganggang juga jauh lebih kecil dibandingkan eceng gondok (Eichornia crassipes). Tumbuhan yang berukuran lebih kecil memiliki kemampuan yang kurang baik dalam mengolah kontaminan. ${ }^{8}$

Selain itu, dijelaskan bahwa kemampuan eceng gondok untuk menyerap logam disebabkan oleh eceng gondok mempunyai akar yang bercabang-cabang halus yang berfungsi sebagai alat untuk menyerap senyawa logam, sehingga toksisitas logam yang terlarut semakin berkurang. ${ }^{15}$ Sehubungan dengan fungsinya sebagai agen penyerap dan penyalur unsur-unsur hara kebagian lain tumbuhan, maka akar akan banyak menyerap unsur hara sehingga akumulasi logam akan lebih tinggi di akar dibandingkan dengan batang dan daun. ${ }^{8}$

Kemampuan akar eceng gondok dalam menyerap senyawa logam yang ada di air ini tidak terlepas dari sistem perakaran yang dimiliki oleh eceng gondok dan aspek fisiologis tumbuhan tersebut. Dimana pada akar eceng gondok dapat dihasilkan suatu zat khelat, yaitu fitosidorof. Zat inilah yang akan mengikat logam dan kemudian akan membawanya ke dalam sel akar. Agar penyerapan logam meningkat, maka pada membran akan terbentuk molekul reduktase. Dengan adanya pembentukan zat khelat dan molekul reduktase ini akan mempermudah logam melintasi epidermis akar dan masuk ke dalam sel-sel akar, sehingga mengakibatkan logam yang terakumulasi tinggi. Terjadinya akumulasi di akar juga disebabkan karena di akar terjadi serapan ion secara aktif, sehingga ion-ion logam tersebut secara aktif terakumulasi di dalam epidermis. ${ }^{5}$

Selain itu, menurut Siska Setyowati, dkk (2009), kemampuan eceng gondok sebagai bioakumulator ini karena pada akarnya terdapat mikroba rhizosfera yang mengakumulasi logam berat. Menurut Suriawiria, 1993 dalam Siska Setyowati, dkk, 2009, mikroba rhizosfera adalah bentuk simbiosis antara bakteri dengan jamur, yang mampu melakukan penguraian terhadap bahan organik maupun anorganik yang terdapat dalam air serta menggunakannya sebagai sumber nutrisi. ${ }^{16}$

Berbeda halnya dengan eceng gondok, ganggang memiliki efisiensi penurunan kadar logam berat $\mathrm{Cu}$ yang lebih kecil dibandingkan eceng gondok, akan tetapi tetap saja ganggang memiliki kemampuan sebagai fitoremediator. Hal ini terjadi karena akar tanaman ganggang ikut berperan dalam proses penyerapan logam $\mathrm{Cu}$. Dimana pada bagian akar tersebut terdapat mikroorganisme yang dapat menyerap logam $\mathrm{Cu}$. Mikroorganisme yang terdapat pada akar tanaman ganggang adalah mikhoriza yang berperan dalam penyediaan unsur hara bagi tanaman. Penyerapan logam $\mathrm{Cu}$ oleh mikroorganisme tersebut memerlukan bantuan khelat (Chelat) yang digunakan untuk penyerapan dan pengangkutan unsur logam esensial. Khelat seperti asam mugienik adalah contoh yang dapat mengikat logam. Khelat adalah zat yang terdiri atas banyak ligan yang mengikat logam (atom yang berwarna) yang ditunjukkan pada Gambar 2, khelat tersebut juga mampu mengikat dan menstabilkan logam beracun. Ikatan dari khelat yang kuat mampu mengubah logam menjadi non-toksik. ${ }^{6}$

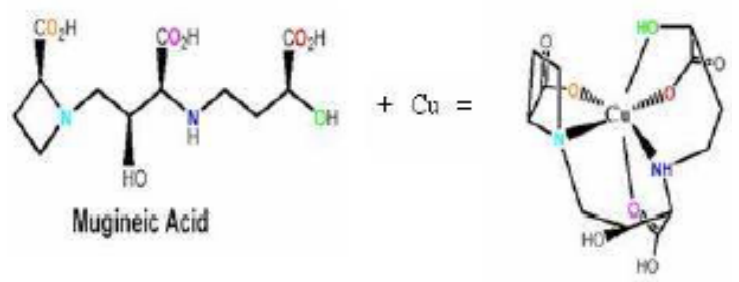


Gambar 2. Ikatan khelat dengan logam $\mathrm{Cu}$ pada penyerapan logam oleh ganggang (Sumber: Sri Sumiyati, dkk., 2009.

Riset-riset fisiologi, biokimia, dan genetika molekuler mengungkapkan bahwa adanya perbedaan yang besar dalam kemampuan mengakumulasi dan mentolerir logam pada tanaman hiperakumulator dengan tanaman normal adalah karena adanya perbedaan dari serangkaian proses fisiologis biokimia dan serangkaian ekspresi gen-gen yang berperan dalam proses penyerapan, akumulasi dan toleransi tanaman terhadap logam. ${ }^{17}$

Selain mengukur kadar tembaga pada limbah yang telah melalui proses uji fitoremediasi, peneliti juga melakukan analisis terhadap kadar $\mathrm{Cu}$ yang berada pada kolam pembuangan akhir pabrik karet tersebut. Dimana, kadar logam berat tembaga pada kolam pembuangan akhir di pabrik tersebut adalah 0,0277 ppm. Dimana kadar logam berat $\mathrm{Cu}$ nya masih aman, karena belum melampaui ambang batas maksimal logam $\mathrm{Cu}$ yang ditetapkan oleh Dep. Kes. R.I., yakni sebesar 1,5 mg/L atau 1,5 ppm. ${ }^{2}$ Akan tetapi, jika kadar tembaga pada kolam pembuangan limbah akhir ini dibandingkan dengan hasil penurunan kadar logam berat tembaga oleh eceng gondok, maka bisa dikatakan bahwa penurunan kadar tembaga menggunakan eceng gondok sedikit lebih baik, dimana tumbuhan air eceng gondok dapat menurunkan kadar logam berat hingga menjadi 0,0144 ppm. Tetapi, sulit untuk membandingkan keakuratan perbandingan ini, karena waktu pembuangan masing-masing limbah pada kolam pertama dan akhir berbeda dan jarak antar kolam pun cukup jauh. Selain itu, ada juga faktor lain seperti misalnya pengendapan logam berat tembaga pada bagian dasar kolam akibat gaya gravitasi.

\section{Kesimpulan}

Berdasarkan penelitian yang telah dilakukan, dapat disimpulkan bahwa: efisiensi penurunan (\%) rata-rata kadar logam berat tembaga oleh eceng gondok lebih besar dari pada efisiensi penurunan rata-rata kadar logam berat tembaga oleh ganggang. Dimana, efisiensi penurunan (\%) rata-rata kadar logam berat tembaga oleh eceng gondok dan ganggang masing-masing sebesar 82,8368\% dan $63,4042 \%$. Sehingga dapat dikatakan bahwa penyerapan logam berat tembaga oleh eceng gondok lebih baik dibandingkan penyerapan logam berat tembaga oleh ganggang.

\section{Acknowledgement}

Puji syukur penulis ucapkan kepada Allah SWT yang telah melimpahkan rahmat dan hidayahNya, sehingga penulis dapat menyelesaikan penelitian ini. Serta pada baginda Rasulullah SAW yang menjadi inspirasi bagi kami, para umatnya.

Selanjutnya, penulis ucapan terimakasih kepada ayahanda Zonifa Satria dan ibunda Herlina,S.Pd. Serta kepada bapak Lazulva, M.Si selaku pembimbing skripsi.

Ucapan terimakasih juga penulis sampaikan kepada Rektor beserta staf UIN Suska Riau. Serta kepada Kepala labor dan laboran laboratorium PEM UIN Suska Riau, Laboratorium Ilmu Tanah Universitas Riau dan UPT Pengujian Material Dinas Bina Marga Kota Pekanbaru. Selanjutnya kepada pihak validator, serta para responden di SMK Farmasi Ikasari Pekanbaru.

\section{Referensi}

1. E. Widjajanti. (2009, November). "Penanganan Limbah Laboratorium Kimia." Kegiatan PPM Prodi Pendidikan Kimia FMIPA UNY. hlm. 1.

2. C. T. Sutrisno dan E. Suciastuti. (2010, Agustus). Teknologi Penyediaan Air Bersih. (edisi 7).

3. Fahruddin. (2014, Februari). Bioteknologi Lingkungan. (edisi 2).

4. H. Palar. (2004, Oktober). Pencemaran dan Toksikologi Logam Berat. (edisi 2).

5. Suwondo, Y. Fauziah, Syafrianti dan S. Wariyanti. (2005, Januari). “Akumulasi Logam Cupprum (Cu) dan Zincum (Zn) di Perairan Sungai Siak dengan Menggunakan Bioakumulator Eceng Gondok (Eichornia crassipes)." Jurnal Biogenesis. 1(2), hlm. 54.

6. S. Sumiyati, D. S. Handayani dan W. Hartanto. (2009, September). "Pemanfaatan Hydrilla (Hydrilla verticilata) untuk Menurunkan Logam Tembaga $(\mathrm{Cu})$ dalam Limbah Elektroplating." Jurnal Presipitasi. 7 (2), hlm. 26.

7. I.G. Gandjar dan A. Rohman. (2012). Kimia Farmasi Analisis. (edisi 10).

8. U. R. Puspita, A. S. Siregar dan N. V. Hidayati. (2011, Februari). "Kemampuan Tumbuhan Air Sebagai Agen Fitoremediator Logam Berat Kromium (Cr) yang Terdapat Pada Limbah Cair Industri Batik." Jurnal 
Penelitian Berkala Perikanan Terubuk. 39(1), hlm. 60-63.

9. Badan Standarisasi Nasional (BSN). (2004, Januari). "Air dan Limbah-Bagian 6; Cara Uji Tembaga $(\mathrm{Cu})$ dengan Spektrofotometri Serapan Atom (SSA)-Nyala." Standar Nasional Indonesia (SNI) 06-6989.6. hlm. 1-3.

10. Giyatmi, Z. Kamal dan D. Melati. (2008, Agustus). "Penurunan Kadar $\mathrm{Cu}, \mathrm{Cr}$ dan $\mathrm{Ag}$ dalam Limbah Cair Industri Perak di Kotagede Setelah Diadsorpsi dengan Tanah Liat dari Daerah Godean." Seminar Nasional IV SDM Teknologi Nuklir. hlm. 102.

11. N. Komari, A. Irwan dan E. Susilawati. (2007, April). "Kajian Adsorpsi $\mathrm{Cu}(\mathrm{II})$ dengan Biomassa Hydrilla verticillata Teraktivasi." Jurnal sains MIPA. 13(1), hlm. 37.

12. Putri, Afdal dan D. Puryanti. (2004, Juli). "Profil Pencemaran Air Sungai Siak Kota Pekanbaru dari Tinjauan Fisis dan Kimia." Jurnal Fisika Unand. 3(3), hlm. 194-195.

13. M. Haryati, T. Purnomo dan S. Kuntjoro. (2012, September). "Kemampuan Tanaman Genjer (Limnocharis Flava (L.) Buch.) Menyerap Logam Berat Timbal $(\mathrm{Pb})$ Limbah Cair Kertas pada Biomassa dan Waktu Pemaparan yang Berbeda.” Jurnal LenteraBio. 1(3), hlm. 136-137.

14. Y. D. Yatimah. "Analisa Cemaran Logam Berat Kadmium dan Timbal pada Beberapa Merk Lipstik yang Beredar di Daerah Ciputat dengan Menggunakan Spektrofotometri Serapan Atom (SSA)." Skripsi. UIN Syarif Hidayatullah. Jakarta. 2014.

15. N. Kholidiyah. "Respon Biologis Tumbuhan Eceng Gondok (Eichornia crassipes Solms) sebagai Biomonitoring Pencemaran Logam Berat Cadmium $(\mathrm{Cd})$ dan Plumbum $(\mathrm{Pb})$ pada Sungai Pembuangan Lumpur Lapindo, Kecamatan Porong, Kabupaten Sidoarjo." Skripsi. UIN Maulana Malik Ibrahim. Malang. 2010.

16. S. Setyowati, N. H. Suprapti dan E. Wiryani. (2009). "Kandungan Logam Tembaga (Cu) dalam Eceng Gondok (Eichornia crassipes Solms.), Perairan dan Sedimen Berdasarkan Tata Guna Lahan di Sekitar Sungai Banger Pekalongan." Jurnal FMIPA UNDIP. hlm. 5.

17. N. Hidayati. (2013, Juli). "Mekanisme Fisiologis Tumbuhan Hiperakumulator Logam Berat.” Jurnal Teknologi Lingkungan. 14(2), hlm. 77. 